\title{
The School Principals Health and Wellness Status for Quality Education Service Delivery in Enugu State
}

\author{
Igwebuike, Felicia Kenechukwu \\ College of Agriculture and Science Education \\ Michael Okpara University of Agriculture,Umudike, Umuahia Abia State,Nigeria
}

\author{
Doi:10.5901/mjss.2013.v4n12p67
}

\begin{abstract}
This study examined the school principal's health and wellness status as a determinant to quality educational service delivery in secondary schools in Enugu State, Nigeria. Survey research designed was adopted for the study. The population of the study consisted of all the principals in the six educational zones numbering 283 principals. The instrument used was a questionnaire which comprised 23 items. The study was guided by two research questions. Data collected were analysed using Mean Score and Standard deviation for the research questions and t-test statistics at 0.005 level of significance for the hypotheses. The findings of the study showed that the principal's health and wellness status has a positive influence in his educational service delivery to secondary education. The study also revealed some promotional and preventive measures to enhance the school principal's health and wellness status. Based in the findings, the study recommended among others that the government, the principal should work towards and implement measures that will enhance the school principal's health and wellness status for effective and quality educational service delivery.
\end{abstract}

Keywords: Principal, Health, Education, Service, Delivery

\section{Introduction}

The secondary school system is seriously facing the problem of not providing good quality education and poor service delivery. Effective service delivery is a challenge facing our schools today. In this era of more services in the field of educational leadership, the school principal is facing a lot of challenges which include population explosion of students, several reforms and development -driven (NEEDS and MDGs) programmes and new circular including HIVIAIDS, entrepreneurship, civics, computer education etcetera. The school principal's health and wellness status determines to a large extent how effectively he contends with these and many other emerging global developments within the school system.

The school principal according to Olosunde, (2008) is an administrator who most of the times runs a school for a purpose, but who once in a while sees the need for modification and is able to effect necessary changes in the school to make it effective. He is an astute social engineer, human manager and resource optimizer. Ogakwu (2009) described the school principal as one who serves as the educational leader and chief executive of a secondary school, to manage effective relationship with students, staff, parents, community and organisations to interpret and implement educational policies and regulations in administering the school and participate in recommending educational policies, procedures and regulations to the school board, and to exercise independent decision as situation warrants. Asuquo (2008) describes the school principal as the head teacher in the school who bears the whole burden of educational structure. He is expected to raise standard, motivate standard, encourage standard and keep standard flying through dedication to duty and methods deemed fit to promote excellence.

Literature is replete with certain attributes/characteristics of an effective school principal. Odo (2009) stated the qualities to include: 
Ability to listen effectively, make and implement effective decision. Have effective communication skill. Empowering, delegating teachers and encouraging them to take risks without fear of penalty for failure. Ability to have organizational system in place so as to be able to respond and follow on multiple requests from students, teachers and government agencies. Tough and diplomatic, a man of integrity and ability to recognize that nobody including himself is infallible.

Asiabeka (2010) observed that the school principal is at the top of the administrative leader of the secondary school. His position involves the control of human and material resources of the school as an organisation. The occupier of the office of school principalship has variously been described as a leader, executive head, supervisor, manger, school climate developer, change facilitator, chief accounting officer and the like all reflecting role perception or expectations. A good competent, effective, efficient and healthy principal is a great asset to the school as a social organisation and the nation as a whole since the present and future of any nation depends to a large extent on the quality off education it provides for the citizenry. The quality of education is determined by the quality of management in that it mobilizes and utilizes the human and material resources available to the school towards the achievement of the school's corporate goals. The school principal's health and wellness status determines how far these goals are achieved.

The relevance of health in every human endeavour can hardly be overstressed as ill health is an impediment to successful living. This amplifies the multidimensional nature of health and reaffirms the World Health Organisation (WHO) definition of health as a state of complete physical, mental and emotional well being and not merely the absence of disease or infirmity. This definition emphasizes three dimensional view of health - the physical, mental and social. In other words, health is wholeness of life. From this it is deduced that the health of an individual extends beyond the functioning of ones body to include feelings, values, reasoning and interpersonal relationships. So there are degrees of health, wellness and ill-health. As an individuals reaches the age of 40 (forty) and above which is the age range of most school principals, he experiences a variety of pathological problems which impinge and militate against effective performance of his administrative duties.

\section{Statement of Problems}

As earlier mentioned, the public secondary school system is seriously facing the problem of not providing good quality education due to poor service delivery. The school principal being the heartbeat and nexus of all activities in the school need to be healthy to effectively discharge his administrative duties maximally, if not a lot of things will go wrong and ultimately quality in service delivery will be poor. But unfortunately, some school principals probably because of the conflicting societal, professional and economic demands impacting on them are weighed down physically, mentally and emotionally and so could not provide quality educational service. It is on this light that this study tries to find out how the school principals health and wellness status positively affect his administrative responsibilities, thus improve quality educational service delivery in public secondary school in Enugu State.

\section{Purpose of The Study}

The purpose of the study is to

1. To find out how the school principals health and wellness status enhance educational service delivery.

2. To asses measures that could be adopted to improve the health and wellness status of the school principal 


\section{Research Questions}

The following research question guided the study:

1. To what extent will the school principal's health and wellness status affect quality educational service delivery?

2. What measures should be adopted to enhance the health and wellness status of the school principal?

\section{Hypotheses}

The following null hypothesis were formulated to guide the study:

- Ho:1 There is no significant difference in the mean rating scores of urban and rural principals on the health and wellness status of the school principal and quality service delivery.

- $\mathrm{Ho}_{2}$ There is no significant difference in the mean rating scores of urban and rural principals on the measures to ensure the health and wellness status of the school principal.

\section{Methodology}

\subsection{Research Design}

Descriptive survey design was adopted to collect data from principals.

\subsection{Population for the Study}

The population comprised the entire 283 principals in the six educational zones of Enugu State.

\subsection{Instrument for Data Collection}

The instrument for data collection was a questionnaire designed by the researcher titled "Principal Health And Wellness Status for Quality Education Service Delivery (PHWSQESD). It is made up of two clusters consisting 23 items. Cluster 1 consisted of 12 items concerned with how the principals health and wellness status positively affect quality educational service delivery. Cluster 2 consisted 11 items on measures that will enhance the school principal's health and wellness status. The items in the questionnaire were structured on a 4 - point rating scale of Very Great Extent (VGE), Great Extent (GE) Little Extent (LE) and Very Little Extent (VLE)

\subsection{Validation of the Instrument}

The instrument was validated by two lecturers from College of Agriculture and Science Education, Michael Okpara University of Agricullture Umudike, who are experts in Educational Administration and Planning and Measurement and Evaluation respectively

\subsection{Reliability of the Instrument}

Trial test was conducted on 40 principals from Ebonyi State. Cronbach Alpha statistics was used to compute their mean ratings which yielded ' $r$ ' $0.76 ; p<0.05$. 


\subsection{Methods of Data Collection}

The researcher with the help of research assistants distributed and collected the questionnaires from the respondents.

\subsection{Method of Data Analysis}

Data collected were analysed using mean and standard deviation. A mean rating of 2.50 and above were regarded as positive effect. Null hypotheses were tested with t-test of $p<0.05$

\section{Result}

The results of the analysis are presented in Tables according to the research questions and hypotheses that guided the study.

\subsection{Research Question one: To what extent will the health and wellness status of the school principal affect quality education service delivery.}

Table 1. Mean response on principal's health and wellness status as it affect their service delivery.

\begin{tabular}{|c|l|c|c|c|c|c|c|}
\hline \multirow{2}{*}{ S/N } & \multicolumn{1}{|c|}{ Items } & \multicolumn{3}{|c|}{ Urban Principals } & \multicolumn{3}{|c|}{ Rural Principals } \\
\cline { 3 - 8 } & & $\overline{\mathrm{X}}$ & $\mathrm{SD}$ & $\mathrm{DEC}$ & $\overline{\mathrm{X}}$ & $\mathrm{SD}$ & $\mathrm{DEC}$. \\
\hline 1 & Improve on the competence of staff & 2.77 & 1.32 & $\mathrm{GE}$ & 2.75 & 1.12 & $\mathrm{GE}$ \\
\hline 2 & Proper keeping of school records & 3.54 & 0.72 & $\mathrm{VGE}$ & 2.75 & 1.12 & $\mathrm{GE}$ \\
\hline 3 & $\begin{array}{l}\text { Enhance frequent communication with Teachers and } \\
\text { students. }\end{array}$ & 2.95 & 0.89 & $\mathrm{GE}$ & 2.93 & 0.95 & $\mathrm{GE}$ \\
\hline 4 & $\begin{array}{l}\text { Ability to adequately supervise the needs of students to } \\
\text { ensure conducive environment for learning. }\end{array}$ & 3.16 & 1.13 & $\mathrm{GE}$ & 2.94 & 0.99 & $\mathrm{GE}$ \\
\hline 5 & $\begin{array}{l}\text { Enable him develop and promote effective use of } \\
\text { innovative materials in the school. }\end{array}$ & 2.77 & 1.32 & $\mathrm{GE}$ & 2.93 & 1.28 & $\mathrm{GE}$ \\
\hline 6 & $\begin{array}{l}\text { Adequate monitoring of students and teachers to ensure } \\
\text { discipline. }\end{array}$ & 3.04 & 1.22 & $\mathrm{GE}$ & 3.43 & 0.86 & $\mathrm{GE}$ \\
\hline 7 & $\begin{array}{l}\text { Ability to consult with leaders and members of the } \\
\text { parents, teachers and community on issue concerning the } \\
\text { school. }\end{array}$ & 3.10 & 0.11 & $\mathrm{GE}$ & 3.34 & 0.78 & $\mathrm{GE}$ \\
\hline 8 & $\begin{array}{l}\text { Ability to make learning experience more meaningful for } \\
\text { students }\end{array}$ & 3.20 & 0.86 & $\mathrm{GE}$ & 3.24 & 1.03 & $\mathrm{GE}$ \\
\hline 9 & $\begin{array}{l}\text { Effective consultation with leaders and members of the } \\
\text { parent-teachers and community organisation. }\end{array}$ & 3.19 & 1.02 & $\mathrm{GE}$ & 2.75 & 1.12 & $\mathrm{GE}$ \\
\hline 10 & $\begin{array}{l}\text { Effective guidance and counseling services for both staff } \\
\text { and students }\end{array}$ & 3.54 & 0.72 & VGE & 3.34 & 0.78 & GE \\
\hline 11 & $\begin{array}{l}\text { Enforcement of school to rules and regulations for school } \\
\text { discipline. }\end{array}$ & 3.35 & 0.87 & $\mathrm{GE}$ & 3.19 & 0.99 & $\mathrm{GE}$ \\
\hline 12 & $\begin{array}{l}\text { Supervision of adequate application of human and } \\
\text { material resources for quality learning. }\end{array}$ & 3.79 & 0.57 & VGE & 3.19 & 1.15 & GE \\
\hline
\end{tabular}

Table I presents the summary of the responses on how the principal health and wellness status affect quality education service delivery. All items were rated above 2.50. This shows that the principal's health and wellness status makes him render quality service for the attainment of school goals. 


\subsection{Research Question 2. What measures should be adopted to enhance the health and wellness status of the school principal.}

Table 2. Mean responses of principals on measures that will help to enhance their wellness status.

\begin{tabular}{|c|l|c|c|c|c|c|c|}
\hline \multirow{2}{*}{ S/N Items } & \multicolumn{2}{|c|}{ Urban Principals } & \multicolumn{3}{c|}{ Rural Principals } \\
\cline { 5 - 8 } & & $\bar{X}$ & $\mathrm{SD}$ & $\mathrm{DEC}$ & $\overline{\mathrm{X}}$ & $\mathrm{SD}$ & $\mathrm{DEC}$ \\
\hline 13 & $\begin{array}{l}\text { Government to adequately provide and maintain infrastructural } \\
\text { facilities in school. }\end{array}$ & 3.24 & 1.06 & $\mathrm{GE}$ & 2.93 & 1.38 & $\mathrm{GE}$ \\
\hline 14 & Sponsoring of principals to improve their professional skills. & 2.87 & 0.93 & $\mathrm{VGE}$ & 2.72 & 0.60 & $\mathrm{GE}$ \\
\hline 15 & Provision for and timely release of funds for school use. & 3.03 & 1.23 & $\mathrm{GE}$ & 2.72 & 0.60 & $\mathrm{GE}$ \\
\hline 16 & Provision of support service amenities for principals. & 3.16 & 1.02 & $\mathrm{GE}$ & 2.72 & 0.96 & $\mathrm{GE}$ \\
\hline 17 & $\begin{array}{l}\text { Adequate supply of human resources and maintenance of } \\
\text { material resources }\end{array}$ & 2.86 & 0.91 & $\mathrm{GE}$ & 3.16 & 0.94 & $\mathrm{GE}$ \\
\hline 18 & Payment of staff salaries and benefits as and when due. & 2.95 & 0.89 & $\mathrm{GE}$ & 2.93 & 0.95 & $\mathrm{GE}$ \\
\hline 19 & Principals to change unhealthy life style & 3.20 & 0.86 & $\mathrm{GE}$ & 3.24 & 1.03 & $\mathrm{GE}$ \\
\hline 20 & Adequate rest and relaxation. & 3.24 & 1.06 & $\mathrm{GE}$ & 2.93 & 1.28 & $\mathrm{GE}$ \\
\hline 21 & Regular exercise. & 2.77 & 1.32 & $\mathrm{GE}$ & 2.93 & 1.28 & $\mathrm{GE}$ \\
\hline 22 & Taking good nutrition and proper hygiene. & 2.98 & 1.00 & $\mathrm{GE}$ & 2.75 & 1.12 & $\mathrm{GE}$ \\
\hline 23 & Proper management of stress. & 2.87 & 0.93 & VGE & 2.72 & 0.60 & $\mathrm{GE}$ \\
\hline
\end{tabular}

Table 2 Presents the mean scores on measures to enhance principal health and wellness status. All the II items rated high above 2.50 . This indicates that all the measures were accepted as means of enhancing the principal's health and wellness status.

Table 3: t-test analysis of mean difference between urban and rural principals response on the extent principals health and wellness status enhances his service delivery.

\begin{tabular}{|c|l|c|c|c|c|c|c|}
\hline S/N & \multicolumn{1}{|c|}{ Source } & No & X & SD & df & t-cal & t-val \\
\hline 1 & Urban Principals & 198 & 2.93 & 0.95 & & & \\
\hline 2 & Rural Principals & 85 & 2.95 & 0.88 & 280 & 0.54 & 1.96 \\
\hline
\end{tabular}

Table 3 shows that the t-calculated value of 0.54 degree of freedom at 0.05 level significance. Therefore, the null hypothesis is accepted. There is no significant difference between mean responses of urban and rural principals on the extent principal's health and wellness status affect quality education service delivery.

Table 4

\begin{tabular}{|c|l|c|c|c|c|c|c|}
\hline S/N & \multicolumn{1}{|c|}{ Source } & No & $\mathrm{X}$ & $\mathrm{SD}$ & $\mathrm{df}$ & $\mathrm{t}-\mathrm{cal}$ & $\mathrm{t}$-val \\
\hline 1 & Urban Principals & 198 & 3.04 & 1.9 & & & \\
\hline 2 & Rural Principals & 85 & 3.10 & 0.96 & 280 & 0.43 & 1.96 \\
\hline
\end{tabular}

Table 4 shows the t-calculated value of 0.43 is less than t-critical value at 1096 at 280 degree of freedom at 0.05 level of significant. The second null hypothesis is therefore accepted. This means there is no significance difference in the mean scores of principal in urban and rural areas on measures to enhance the principal's health and wellness status.

\section{Discussion of Findings}

From the findings of the study, it is clear that a principal's health and wellness status effect the administrative 
roles which positively or negatively influence his education service delivery. A principal in high level of health and wellness presents a wonderful personality. $\mathrm{He}$ is in a position to achieve both personal and society group goals. His input in education service delivery is enhanced. According to Odo (2009) the principal's health and wellness status enable him to provide direction, asses, exercise influence, mobilize and work with others to articulate and achieve the shared goals, objectives, interest and intensions of all stakeholders in the school system. Ogakwu (2009) opined that the principals health and wellness status will enable him maintain sensitive and mutual beneficial relationship with the community such as the utilization of community parental resources for the benefit of school programmes and activities. In line with the above assertion, Ekwudalo (2010) observed that the principals health and wellness status helps in better communication, efficient educational service and enhanced students, staff and school community relationship. A healthy principal is disposed to provide effective staff and students personal services in the areas of staff motivation and self development, students feeding, health services, guidance and counseling for both staff and students and generally promote conducive environment for the achievement of educational goals. Such a principal finds life worth living, always happy, understanding and relate with people around him satisfactory, functions optimally and wellness status.

The respondents agreed to all the 11 items in table 2 as measures to enhance the principal's health and wellness status. It is their general consensus that the health and wellness status of the principal will be enhanced and sustained if the government adopt such measures as providing schools with enough human material and financial resources which gives the principal an enabling environment to carry out his roles effectively. This gives credence to Madubum (2000) findings which noted that inadequate resources and facilities are stressors for some principals. He maintained that the quality of education received by students bear direct relevance to the availability of resources and over all atmosphere in which learning takes place. The principal will be emotionally and mentally stressed if infrastructures are dilapidated, place of convenience not available and inadequate staffers who should help in moving the school to greater height.

On the issue of prompt payment of salaries by government, Abanobi (2005) observed that the issue of late payment of salary is a major cause of mental and emotional health hazard for the principal. He opined that principals and staff salaries should be paid as and when due and their promotion not stagnated. Supporting the above assertion, Odo (2009) noted that the principals take home pay is not commensurate with his productivity. He is not given any bonus, car nor house loan. The politicians only take care of themselves neglecting the teachers and the principals. Today councilors who barely passed senior school certificate examination (SSCE) receive better pay and posh cars despite the principal's plethora of degree certificates and experiences. Even the much he receives at the end of each month cannot sustain him and his family because of inflation. All these are stressors for the principal which affect his health and wellness status.

Heaven it is said help those who help themselves. This is true to the responses of principals to items on Table 11. The principals themselves need to adopt these promotional and preventive measures for enhancing their health and wellness status, which include good nutrition, change in life style, adequate rest/ relaxation, regular exercise and proper hygiene. Principals should be exposed to health education which probes into and redirects life styles, habits and behaviours that cause health problems for man. Madubum (2009) observed that health is maintained and improved not only through the advancement and application of health services, but also through the efforts and intelligent lifestyle choices of the individual and society. He stated four general determinants of health as -human biology, environment, lifestyle and health care services.

The principal should eat food rich protein, minerals, vitamins, fruits, vegetables and less carbohydrate to avoid obesity, diabetes and heart diseases. This supports Akubuo (2000) whose study observed that as one grows older he drops certain habits which is detrimental to his health. Regular exercise is good for the principal as it enhances physical, mental and emotional wellbeing of any individual. Akubuo (2000) still maintained that regular exercise improves blood circulation, help the immune system, control blood pressure, 
strengthen the hearts, lungs, muscles, bones. Increase emotional stability, decrease anxiety, depression, tension and stress. It should then be rightly stated that much of the ill health suffered by man could be prevented through wise and effective dissemination and inculcation of beneficial health habits and practices.

\section{Conclusion}

Every planned curriculum has quality built into it. This quality can materialize depending in the centrifugal circumstances surrounding its implementation of which the principal's health and wellness status is one of them. The health and wellness status of the principal who is the nexus of the school contribute immensely to the achievement of education goals through quality educational service delivery. Achieving health and remaining in a wellness state is an active process. Some promotional and preventive measures to ensure the principals health and wellness status were discussed.

\section{Recommendation}

1. Government should give support to measures that ensures principals health and wellness status by ensuring that the environment where the principal operate is conducive through provision of and maintenance of human and material resources.

2. Principal's salary should be commensurate with his work, education and experience.

3. Principals need to be motivated by giving them such incentive as car and housing loan.

4. Inculcation of health education will help the principal know and implement preventional and promotional health measures.

5. Without good health, the enthusiasm and capacity to deliver will not be their. Therefore, Nigerian Health Insurance Scheme should be provided for principals just as their counterparts in the federal school.

\section{References}

Abanobi, O.C (2005). Health: Wellness and IIIness State: Owerri Opinion Research and Communication Inc.

Akubue, P.I (2000). Health Checks and Health Promotion. Your guide to a long life active life.

Asiabeka, I.P (2010) The need for effective facility management in schools in Nigeria.New York Science Journal http://www.sciencepub.org

Asuquo, P.N (2008). The Place of Quality Control and the Role of the Nigerian Secondary School Principal enhancing Service Delivery. Principals year book 2008

Ekundalo, H.T. (2010) Administering Secondary Schools in Nigeria for quality Output in the 21st century. The Principals Challenge. European journal of Educational Studies

Madubum, M.A. (2000) Occupational stress factors Among secondary School Principals in Abia State, Nigeria. International Journal of Educational Planning and Administration (1) 17-27

Odo, M.E(2009) The Principals, His Health and wellness and Productivity. Paper presented at Mandatory Continuing Professional Training(MCPT) ANCOPPS programme, South East Zone Enugu.

Ogakwu, V.N(2009). Refocusing the Principalship. Staff Motivation, Supervision and Discipline. Paper prevented at a workshop for Principals organized by Post Primary School Management Board (PPSMB) Enugu State

Olosunde, S.J. (2008) Capacity Building and Developing the Professional Skills of Principals and Teachers in P.N.C Ngwu (ed) Principals Year Book 2008. Pg 303 
